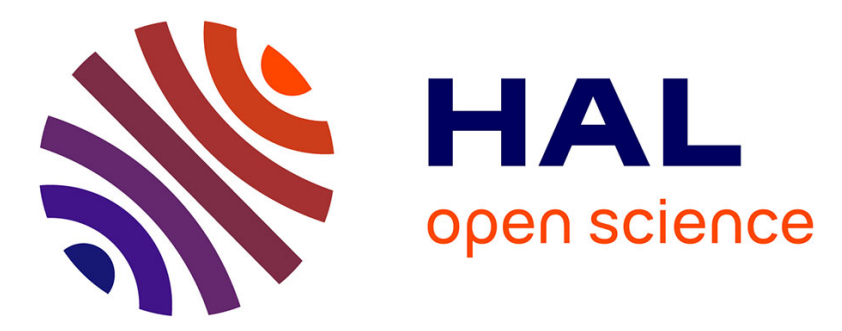

\title{
Differences in foraging and broodnest temperature in the honey bees Apis cerana and A. mellifera
}

Ken Tan, Shuang Yang, Zheng-Wei Wang, Sarah Radloff, Benjamin Oldroyd

\section{To cite this version:}

Ken Tan, Shuang Yang, Zheng-Wei Wang, Sarah Radloff, Benjamin Oldroyd. Differences in foraging and broodnest temperature in the honey bees Apis cerana and A. mellifera. Apidologie, 2012, 43 (6), pp.618-623. 10.1007/s13592-012-0136-y . hal-01003658

\section{HAL Id: hal-01003658 \\ https://hal.science/hal-01003658}

Submitted on 1 Jan 2012

HAL is a multi-disciplinary open access archive for the deposit and dissemination of scientific research documents, whether they are published or not. The documents may come from teaching and research institutions in France or abroad, or from public or private research centers.
L'archive ouverte pluridisciplinaire HAL, est destinée au dépôt et à la diffusion de documents scientifiques de niveau recherche, publiés ou non, émanant des établissements d'enseignement et de recherche français ou étrangers, des laboratoires publics ou privés. 


\title{
Differences in foraging and broodnest temperature in the honey bees Apis cerana and A. mellifera
}

\author{
Ken TAN ${ }^{1,2}$, Shuang $\mathrm{YANG}^{2}$, Zheng-Wei $\mathrm{WANG}^{2}$, Sarah E. RAdLOFF ${ }^{3}$, \\ Benjamin P. OLDROYD ${ }^{4}$

\footnotetext{
${ }^{1}$ Key Laboratory of Tropical Forest Ecology, Xishuangbanna Tropical Botanical Garden, Chinese Academy of Sciences, Yunnan, People's Republic of China Republic of China

${ }^{3}$ Department of Statistics, Rhodes University, Grahamstown 6140, Republic of South Africa

${ }^{4}$ School of Biological Sciences, University of Sydney, Sydney, NSW 2006, Australia
} \\ ${ }^{2}$ Eastern Bee Research Institute, Yunnan Agricultural University, Heilongtan, Kunming, Yunnan Province, People’s
}

Received 18 December 2011 - Revised 23 February 2012 - Accepted 12 March 2012

\begin{abstract}
This study aims to explore the effect of ambient temperature on foraging the activity of Apis cerana and Apis mellifera colonies. We recorded ambient temperature, the time at which foraging commenced, worker thoracic temperature, and brood nest temperature at the same apiary in Kunming, China. We found that A. cerana start foraging earlier and at lower temperatures than do A. mellifera. A. cerana foraging (departures per minute) also peaked earlier and at lower temperature than did A. mellifera foraging. At the same ambient temperature, departing $A$. mellifera foragers and workers sampled from the brood nest had a higher thoracic temperature than departing A. cerana foragers and brood nest workers. A. mellifera colonies also maintained their brood nest temperature significantly higher than did $A$. cerana. Our results suggest that the larger $A$. mellifera foragers require a higher thoracic temperature to be able to forage.
\end{abstract}

Apis cerana / Apis mellifera / foraging temperature / thoracic temperature

\section{INTRODUCTION}

The ecological success of honey bees depends in part on their ability to thermoregulate and to thereby forage at lower temperatures than competing bee species (Goulson 2003). The internal temperature of a honey bee, Apis mellifera, nest is maintained at a relatively constant temperature around 34.5-35.5 ${ }^{\circ} \mathrm{C}$ (Bujok et al. 2002; Kleinhenz et al. 2003; Jones et al. 2004). This means that honey bee foragers are prewarmed and can commence foraging before most solitary bees or stingless bees (Jones and Oldroyd 2007).

Corresponding author: B.P. Oldroyd, benjamin.oldroyd@sydney.edu.au Manuscript editor: James Nieh
Furthermore, although already warm from the heat generated within their nest, embarking $A$. mellifera foragers further elevate their thoracic temperature $\left(T_{\mathrm{Th}}\right)$ before flight to between 36 and $38{ }^{\circ} \mathrm{C}$ by shivering their wing muscles (Heinrich 1979). At low $\left(<20{ }^{\circ} \mathrm{C}\right)$ ambient temperatures $\left(T_{\mathrm{A}}\right)$, honey bees of several species can maintain their $T_{\mathrm{Th}}$ above $30{ }^{\circ} \mathrm{C}$ while foraging (Heinrich 1979; Dyer and Seeley 1987), as a byproduct of flight muscle activity (Heinrich 1993; Dudley 2000), and in some instances utilizing warming zones created by the morphology of the flowers that they visit (Kevan 1975) or selecting flowers with warmer nectar (Dyer et al. 2006; Norgate et al. 2010).

In order to fly, an insect must attain a minimum $T_{\mathrm{Th}}$ (Heinrich 1979; Dyer and Seeley 
1987) that is species specific. Thus, the first honey bee colonies in which the foragers can achieve this minimum temperature can commence foraging before competing colonies and solitary bees, potentially benefiting from uncontested access to floral resources. Asian honey bees vary greatly in size and nesting behavior (Ruttner 1988), and this in turn influences their ability to thermoregulate and achieve the minimum $T_{\mathrm{Th}}$ required for flight (Dyer and Seeley 1987). Oldroyd and Wongsiri (2006) argued that the different thermoregulatory abilities of Asian honey bees results in resource partitioning among the species, thereby reducing interspecific competition. Oldroyd et al. (1992) showed that the medium-sized cavity-nesting species $A$. cerana is able to forage earlier than the opennesting giant bees and dwarf bees, probably because their nests are better thermoregulated (Dyer and Seeley 1991) and because A. cerana is able to achieve a greater differential between $T_{\mathrm{Th}}$ and $T_{\mathrm{A}}$ as a result of endogenous heat production (Dyer and Seeley 1987).

The Western honey bee A. mellifera was introduced to China a little more than 100 years ago (Yang 2005). A. mellifera has been extensively propagated by beekeepers and is now extant throughout China. In recent years, the number of domestic colonies has surpassed 7 million (Yang 2005). Simultaneously, beekeeping with indigenous $A$. cerana has declined, and there is some evidence that wild populations of A. cerana are also in decline, in part because of direct competition with A. mellifera ( $\mathrm{Ji}$ et al. 2003; Yang 2005). This is unfortunate because it has been claimed that the indigenous A. cerana is a more efficient pollinator of plants that bloom in early spring than the $A$. mellifera strains present in China. In particular, it has been claimed that $A$. cerana can commence foraging earlier in the morning and at lower ambient temperatures than can A. mellifera (Yang 2005).

A. mellifera is significantly larger than $A$. cerana (Ruttner 1988). Other things being equal, one would predict that a larger bee species would have greater capacity for endogenous heat production and be able to forage at lower temperatures (e.g., Bartholomew and Heinrich
1981; Dyer and Seeley 1987; Corbet et al. 1993; Bishop and Armbruster 1999). Thus, we predicted that $A$. mellifera should be able to sustain a greater differential between $T_{\mathrm{Th}}$ and $T_{\mathrm{A}}$ than $A$. cerana and, contrary to the suggestion of Yang (2005), should thereby be able to forage earlier in the morning and on colder days than A. cerana.

Here, we explore the relationship between ambient temperature, foraging activity, and bee species at a single location in Kunming, China during winter. Kunming is in the subtropical zone, with winter temperatures in the range of $0-20{ }^{\circ} \mathrm{C}$. Honey bees forage throughout the year in this region.

\section{MATERIALS AND METHODS}

Ten queenright $A$. cerana and 10 queenright $A$. mellifera colonies were placed in an apiary in Yunnan Agricultural University campus, Kunming $\left(102^{\circ} 10^{\prime}-\right.$ $103^{\circ} 40^{\prime}$ longitude, $24^{\circ} 23^{\prime}-26^{\circ} 22^{\prime}$ latitude, $1,890 \mathrm{~m}$ elevation), China. All colonies were housed in standard Langstroth hives and we equalized the colonies so that each contained two frames of brood and two frames of honey and pollen. The experiments were conducted in January of 2010 (three pairs of colonies) and 2011 (seven pairs of colonies) in fine weather $\left(T_{A}\right.$ between 2 and $\left.20^{\circ} \mathrm{C}\right)$.

\subsection{Body and broodnest temperatures}

Observations started in the early morning. When the first bees emerged from the hive entrance for foraging, the ambient temperature was recorded. When the ambient temperature reached $6{ }^{\circ} \mathrm{C}$ and later when it reached $20^{\circ} \mathrm{C}$, we measured the thoracic temperature of each of 10 randomly selected departing foragers and 10 randomly selected workers from the brood nest from each colony with a digital thermometer (Sensortek, BAT12 , with a resolution of $\pm 0.1{ }^{\circ} \mathrm{C}$ ). To obtain a reading, we grasped a bee with rubber-covered forceps and thrust the copper probe (diameter $1 \mathrm{~mm}$ ) about $3 \mathrm{~mm}$ into the bee's thorax until the highest temperature was encountered (Heinrich 1979). Brood nest temperature was also measured by thrusting the copper probe into the center of the brood nest before brood nest bees were sampled. 


\subsection{Body mass and nectar loads}

Body mass was measured for each of the 10 departing and 10 returning foragers caught at the entrance. The mean difference in mass between returning and departing foragers was used as a proxy for the loads carried by returning foragers.

\subsection{Foraging activity}

Foraging activity was measured as the number of exiting bees in a 30-min period for each test colony for test 1 day. Each test ran from 8:30 until 11:30, and fluctuations in the ambient temperature during the test period were recorded on each of the 10 test days.

\subsection{Statistical analysis}

Independent $t$ tests were used to test for differences between the two species in body mass, load, minimum foraging temperature, body thoracic temperature, and brood nest temperature. Repeated measures ANOVA was used to test for species differences in the mean number of foragers over time from 8:30 until 11:30. Prior to analysis, homogeneity of variances and normality of the data were examined using Levene's and Shapiro-Wilk's tests (Johnson and Wichern 2002). Homogeneity of the variances was achieved by applying a square-root transformation.

\section{RESULTS}

\subsection{Body and brood nest temperatures}

There was a significant difference in the $T_{\mathrm{A}}$ at which the $A$. cerana $\left(3.42 \pm 0.11^{\circ} \mathrm{C} ; \pm \mathrm{SE}\right)$ and $A$. mellifera $\left(6.57 \pm 0.17{ }^{\circ} \mathrm{C}\right)$ colonies commenced foraging $\left(t_{58}=15.40, P<0.0001\right)$. When $T_{\mathrm{A}}$ was $6^{\circ} \mathrm{C}, T_{\mathrm{Th}}$ of $A$. mellifera foragers and brood nest bees was significantly higher than those of $A$. cerana, but when the ambient temperature was $20{ }^{\circ} \mathrm{C}$, there was no significant difference in $T_{\mathrm{Th}}$ between the two species. At the same ambient temperature, A. mellifera colonies maintained a significantly higher brood nest temperature than did A. cerana colonies (Table I).

\subsection{Body mass and forager load}

The mass of $A$. mellifera foragers (93.3 \pm $1.7 \mathrm{mg})$ was significantly greater $\left(t_{198}=12.27\right.$, $P<0.0001)$ than that of $A$. cerana foragers $(69.3 \pm 1.0 \mathrm{mg})$. The load carried by $A$. mellifera foragers $(51.0 \pm 1.9 \mathrm{mg})$ was also significantly greater than that carried by $A$. cerana $(31.3 \pm$ $1.2 \mathrm{mg})$ foragers $\left(t_{198}=8.75, P<0.0001\right)$.

\subsection{Foraging activity}

There was a significant difference between the species in the mean number of foragers from 08:30 to 11:30 in each 30-min period (species, $F_{1,18}=50.05, P<0.0001$; time, $F_{5,90}=144.43, P<$ 0.0001 ; interaction, $F_{5,90}=21.01, P<0.0001$; Fig. 1). A. cerana foraging activity reached its peak around 10:00, at which time the ambient temperature was only about $10^{\circ} \mathrm{C}$. In contrast, $A$. mellifera-foraging activity reached its peak at around 11:30 at which time ambient temperature had reached about $20^{\circ} \mathrm{C}$ (Fig. 1).

\section{DISCUSSION}

The ecotype of $A$. cerana that is indigenous to Kunming starts foraging and reaches the peak of foraging activity earlier and at a lower $T_{\mathrm{A}}$ than does exotic $A$. mellifera. A. mellifera foragers apparently require a higher minimum $T_{\mathrm{A}}$ and $T_{\mathrm{Th}}$ than $A$. cerana foragers before they commence foraging. Thus, we reject our hypothesis that the larger $A$. mellifera should be able to generate higher $T_{\mathrm{Th}}$ than $A$. cerana and thus fly at cooler temperatures. Instead, we support the contention of Yang (2005) that $A$. cerana in the Kunming region forage temperatures than do $A$. mellifera. This suggests that $A$. cerana should outcompete $A$. mellifera during cooler weather. We also support the view of Yang (2005) that if $A$. cerana is driven extinct in the future, $A$. mellifera may not fully replace the pollinating activities of $A$. cerana. Thus, the decline in A. cerana populations in China has potential inimical effects on any indigenous flora that is adapted to A. cerana pollination 
Table I. Mean thoracic temperature, and brood nest temperature (degrees Celcius $\pm \mathrm{SE}$ ) in 10 co-located $A$. cerana and A. mellifera colonies.

\begin{tabular}{lllcc}
\hline Ambient temperature $\left({ }^{\circ} \mathrm{C}\right)$ & Measurement & A. cerana & A. mellifera & $P$ \\
\hline 6 & Departing forager $T_{\mathrm{Th}}$ & $21.8 \pm 0.23$ & $23.6 \pm 0.22$ & $<0.0001$ \\
& Brood nest workers $T_{\mathrm{Th}}$ & $14.5 \pm 0.16$ & $19.7 \pm 0.16$ & $<0.0001$ \\
& Brood nest $T$ & $33.1 \pm 0.05$ & $34.1 \pm 0.05$ & 0.001 \\
20 & Departing forager $T_{\mathrm{Th}}$ & $30.7 \pm 0.3$ & $31.4 \pm 0.2$ & 0.052 \\
& Brood nest workers $T_{\mathrm{Th}}$ & $28.9 \pm 0.3$ & $29.2 \pm 0.2$ & 0.466 \\
& Brood nest $T$ & $33.7 \pm 1.8$ & $34.2 \pm 0.9$ & 0.006 \\
\hline
\end{tabular}

(Ji et al. 2003). Some early-flowering crops may also be less well pollinated.

The $T_{\mathrm{Th}}$ of bees in the brood and the overall broodnest temperature was slightly higher for $A$. mellifera than for A. cerana, especially at low $T_{\mathrm{A}}$. This suggests that $A$. cerana maintains a lower brood nest temperature than $A$. mellifera. There is likely a tradeoff between energy expenditure on nest thermoregulation and the benefits of a higher and more stable brood nest temperature for brood development (Jones et al. 2005). A. cerana has apparently evolved to tolerate a lower and more variable brood nest temperature than $A$. mellifera, perhaps paying a price of less canalized brood development. $A$ mellifera has apparently evolved towards a very stable brood nest temperature, gaining the benefits of uniform brood development, but paying the cost of greater energetic expenditure on maintaining a stable brood nest temperature.

Maintaining an elevated $T_{\mathrm{Th}}$ while foraging requires energy expenditure, but allows foragers to carry heavier loads because they can generate greater mass-specific lift (Harrison and Fewell

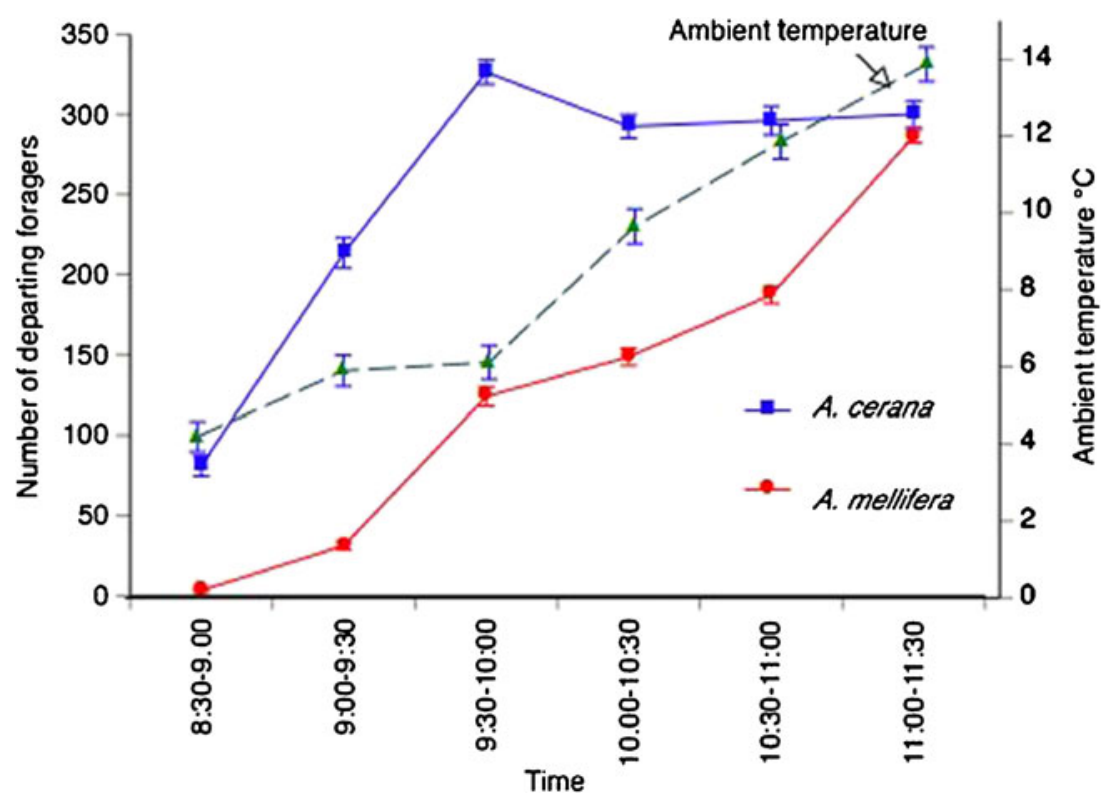

Figure 1. Mean number of A. cerana and A. mellifera foragers observed every $30 \mathrm{~min}$ from 08:30 to 11:30 $(n=$ 10 colonies each) relative to temperature. Error bars are standard error of the mean. 
2002). Collectively, thermoregulation by foragers represents a considerable metabolic expense for a colony, which must be balanced against their greater foraging efficiency. It appears that $A$. cerana trades lower foraging efficiency for greater metabolic efficiency, whereas in $A$. mellifera the compromise is reversed.

All honey bee species examined too date maintain a $T_{\mathrm{Th}} 5-6{ }^{\circ} \mathrm{C}$ above $T_{\mathrm{A}}$ when foraging at cool temperatures (Dyer and Seeley 1987). Coelho (1991) argued that $A$. mellifera require a $T_{\mathrm{Th}}>28{ }^{\circ} \mathrm{C}$ in order to generate sufficient force to lift off. Heinrich (1979) suggested that departing A. mellifera foragers actively warm up their flight muscles before commencing foraging, often achieving $T_{\mathrm{Th}}$ that is greater than workers in the brood nest. We found that departing foragers of both species had lower $T_{\mathrm{Th}}$ than brood nest workers. We cannot account for this difference in findings.

\section{ACKNOWLEDGMENTS}

Financial support was granted by Key Laboratory of Tropical Forest Ecology, Xishuangbanna Tropical Botanical Garden, Chinese Academy of Sciences and Yunnan Agricultural University of China.

Différences de température, pour le butinage et dans le nid à couvain, entre les abeilles Apis cerana et $A$. mellifera.

Apis cerana / Apis mellifera / température ambiante / début du butinage / température thoracique

Unterschiede in Sammel- und Brutnesttemperaturen bei den Honigbienenarten Apis cerana und A. mellifera

Apis cerana/Apis mellifera / Sammeltemperatur / Thoraxtemperatur

\section{REFERENCES}

Bartholomew G.A., B. Heinrich (1981) A matter of size: an examination of endothermy in insects and terrestrial vertebrates, In: Heinrich B. (Ed.), Insect thermoregulation, pp. 46-78. Wiley, New York,
Bishop J.A., W.S. Armbruster (1999) Thermoregulatory abilities of Alaskan bees: effects of size, phylogeny and ecology. Funct. Ecol. 13, 711-724

Bujok B., M. Kleinhenz, S. Fuchs, J. Tautz (2002) Hot spots in the bee hive. Naturwissenschaften 89, 299-301

Coelho J.R. (1991) Thee effect of thorax temperature on force production during tethered flight in honeybee (Apis mellifera) drones, workers, and queens. Physiol. Zool. 64, 823-825

Corbet S.A., M. Fussell, R. Ake, A. Fraser, C. Gunson, A. Savage, K. Smith (1993) Temperature and the pollinating activity of social bees, Ecol. Entomol. 18, $17-30$

Dudley R. (2000) The biomechanics of insect flight, Priceton University Press, Princeton NJ.

Dyer F.C., T.D. Seeley (1987) Interspecific comparisons of endothermy in honeybees (Apis): deviations from the expected size-related patterns. J. Exp. Biol. 127, 1-26

Dyer F.C., T.D. Seeley (1991) Nesting behavior and the evolution of worker tempo in four honey bee species. Ecology. 72, 156-170

Dyer A.G., H.M. Whitney, S.E.J. Arnold, B.J. Glover, L. Chittka (2006) Bees associate warmth with floral colour. Nature. 442, 525

Goulson D. (2003) Effects of introduced bees on native ecosytems. Annu. Rev. Ecol. Syst. 34, 1-26

Harrison J.F., J.H. Fewell (2002) Environmental and genetic influences on flight metabolic rate in the honey bee, Apis mellifera. Comp. Biochem. Physiol. A-Mol. Integr. Physiol. 133, 323-333

Heinrich B. (1979) Thermoregulation of African and European honeybees during foraging, attack, and hive exits and returns. J. Exp. Biol. 80, 217-229

Heinrich B. (1993) The hot-blooded insects, Harvard University Press, Cambridge MA

Ji R., B. Xie, G. Yang, D. Li (2003) From introduced species to invasive species - a case study on the Italian bee Apis mellifera L. J. Chin. Ecol. 5, 70-73

Johnson R.A., D.W. Wichern (2002) Applied multivariate statistical analysis, Prentice Hall, Upper Saddle River NJ

Jones J.C., B.P. Oldroyd (2007) Nest thermoregulation in social insects, Adv. Ins. Physiol. 33, 153-191

Jones J., M. Myerscough, S. Graham, B.P. Oldroyd (2004) Honey bee nest thermoregulation: diversity promotes stability, Science 305, 402-404

Jones J., P. Helliwell, M. Beekman, R.J. Maleszka, B.P. Oldroyd (2005) The effects of rearing temperature on developmental stability and learning and memory in the honey bee, Apis mellifera, J. Comp. Physiol. A. 191, 1121-1129

Kevan P.G. (1975) Sun-tracking solar furnaces in high arctic flowers: significance for pollination and insects, Science 189, 723-726

Kleinhenz M., B. Bujok, S. Fuchs, J. Tautz (2003) Hot bees in empty broodnest cells: heating from within, J. Exp. Biol. 206, 4217-4231 
Norgate M., S. Boyd-Gerny, V. Simonov, M.G.P. Rosa, T.A. Heard, A.G. Dyer (2010) Ambient temperature influences Australian native stingless bee (Trigona carbonaria) preference for warm nectar, PLoS ONE 5(8), doi:10.1371/journal. pone. 0012000

Oldroyd B.P., S. Wongsiri (2006) Asian honey bees. Biology, conservation and human interactions, Harvard University Press, Cambridge, MA.
Oldroyd B.P., T.E. Rinderer, S. Wongsiri (1992) Pollen resource partitioning by Apis dorsata, A. cerana, A andreniformis and A. florea in Thailand. J. Apic. Res. 31, 3-7

Ruttner F. (1988) Biogeography and taxonomy of honeybees, Springer-Verlag, Berlin.

Yang G.-H. (2005) Harm of introducing the western honeybee Apis mellifera $\mathrm{L}$. to the Chinese honeybee Apis cerana F. and its ecological impact. Acta Entomol. Sin. 48, 401-406 